Отримано: 2 квітня 2020 p.

Прорецензовано: 14 квітня 2020 р.

Прийнято до друку: 14 квітня 2020 р.

e-mail: ishcherbakova@ukr.net

DOI: $10.25264 / 2415-7384-2020-11-184-188$
Shcherbakova I. N. Professional activity stress factors of health workers. Наукові записки Національного університету «Острозька академія». Серія «Психологія» : науковий журнал. Острог : Вид-во НаУОА, червень 2020. № 11. С. 184-188.

\author{
Iryna M. Shcherbakova, \\ PhD of philosophical sciences, \\ associate professor at the department of psychology, \\ Sumy State A. S. Makarenko Pedagogical University
}

\title{
PROFESSIONAL ACTIVITY STRESS FACTORS OF HEALTH WORKERS
}

The article covers the theoretical analysis results of occupational stress. Occupational stress is defined as a tension state of the labor subject, arising under the influence of emotional-negative and extreme stress factors of professional activity. Attention is focused on professional stress factors as potential stressors, rather than factors that automatically cause stress. Stress factors causing occupational stress in medical workers have been analyzed. The practical study results of the stress factors causing medical workers' occupational stress are also given.

Key words: stress, stress factor, stress resistance, stress-overcoming behavior.

\author{
Щербакова Ірина Миколаївна, \\ кандидат філософських наук, доцент кафедри психологіi \\ Сумського державного педагогічного університету імені А. С. Макаренка
}

\section{СТРЕС-ФАКТОРИ ПРОФЕСІЙНОЇ ДІЯЛЬНОСТІ МЕДИЧНИХ ПРАЦІВНИКІВ}

\begin{abstract}
У статті висвітлено результати теоретичного аналізу професійного стресу. Професійний стрес визначено як напружений стан суб'єкта праці, щзо виникає під впливом емочійно-негативних і екстремальних стрес-факторів професійної діяльності. Акцентовано на професійних стрес-факторах як потенційних стресорах, а не чинниках, які автоматично викликають стрес. Проаналізовано стрес-фактори, ияо викликають професійний стрес у медичних працівників. Наведено результати практичного дослідження стрес-факторів, які обумовлюють професійний стрес у медичних прачівників.
\end{abstract}

Ключові слова: стрес, стрес-фактор, стресостійкість, стрес-переборювана поведінка.

Problem statement. Occupational stress is the worker's tension state which arises under the influence of emotional-negative and extreme factors is related to the performed professional activity. Occupational stresses have a negative impact on the effectiveness of the labor subjects' professional activities. Scientists are trying to find effective means to increase stress resistance of labor subjects, as well as to determine ways to increase labor efficiency. In the context of reforming the medical industry of Ukraine, it is important that each worker understands the nature of occupational stress, has a sufficient level of stress resistance.

Actual scientific researches and issues analysis. Specifics of professional stress manifestation of doctors of different specializations are presented in the works of N. Maliar-Hazda, L. Lototska-Holub, P. Hingley, A. McVicar, G. Engel, J. Worden $[5 ; 8 ; 10 ; 11 ; 12 ; 13]$. Medical workers professional burnout syndrome is investigated by Yu. Savka, L. Lototska-Holub, Ya. Slyvka, I. Poliak-Mytrovska, O. Raiko, H. Savka, L. Yuriieva $[1 ; 8]$. A detailed review of situations that may be stressful in the professional activities of health workers has been made by V. Bozhenko, M. Popyl, I. Levytska [6; 9]. Peculiarities of stress experience by health workers are analyzed in scientific works of K. Rudnieva, E. Kucherenko, O. Shevchenko and others [3; 7].

The aim of the article is to analyze theoretical approaches to the study of stress factors that cause health workers occupational stress and to empirical determination of the causes of doctors and nurses occupational stress.

Materials and methods of research. To achieve the goal, theoretical (analysis, synthesis, comparison, generalization) and empirical ("Causes of stress in your work" technique by Yu. Shcherbatykh) research methods have been applied.

Statement of basic materials. The analysis of scientific literature on the studied problem showed that despite the range of the scientific publications devoted to a professional stress, in the majority of researches the psychological essence of a stress, resistance to stress, manifestation of professional burning out of subjects of work still reveals. We must recognize the absence of a uniform classification of stress factors. This is because most researchers avoid clearly defining stress factors and their classification.

Consequently, we must note that with the absence of a consistent approach to determining the content of the concepts of "professional stress" and "stress resistance", as well as with the absence of clear criteria for 
classifying professional stress factors, in particular in the professional activity of health workers, the problem of stress factors that cause professional stress among medical workers is highly relevant. Due to this, we must say that we share the opinions of O. Raiko, H. Savka, Yu. Savka, Ya. Slyvka, I. Poliak-Mytrovska [1, p. 66] that the popular quotation "Aliis inserviendo consumer" ("Light to others burn myself"), was relevant not only in the 17th century when it was proclaimed by the Dutch doctor Nicolaes van Tulp, but remains relevant today, especially to the professional activities of health workers in the context of the crisis present and transformationreformation processes that are taking place in the medical industry.

Without exaggerating it should be said that situations when healing others medical workers "burn" themselves, happen very often. It is about the syndrome of professional burnout of health workers, which... "it is diagnosed for $46 \%$ of Great Britain doctors (Orton P. et al., 2012), 31,4\% of Hong Kong doctors (Siu C. et al., 2012), 50\% of Brazil pediatricians (Garcia T. et al., 2014), 42,4\% of France doctors (Estryn-Behar M., 2010), 73,3\% of Russia psychiatrists (Zolotukhyna L. V., 2011), 23,5\% of emergency doctors (Fedak B. S., 2007) and 89,3\% of pediatricians of Ukraine (Horachuk V. V., 2009)" [1, p. 67].

Taking the above mentioned into consideration, it should be noted that in previous studies, in particular, the study of the peculiarities of medical workers stress resistance in the context of the medical industry reform (I. Shcherbakova, L. Akentieva, Montreal, 2018), we drew attention to the fact that during the transition period of medical industry reform with the emergence of new specific stress factors, the influence of distress factors can provoke a performance decrement, deterioration of qualitative and quantitative work indicators, reduction of the body adaptation capabilities of labor subjects, as well as cause symptoms of long-term occupational stress [2, p. 140-141].

The term "occupational stress" is used by scientists for generalization of the concepts "working stress", "labor stress", "production stress", "organizational stress" and others. In our study, we define occupational stress as the tense state of the subject of work that occurs when he/she is under the influence of emotional-negative or extreme factors related to the performed professional activity.

It should be noted that a number of authors, in particular K. Rudnieva, E. Kucherenko, exploring stress experiences by health workers of a multidisciplinary hospital, believe that "professional stress is a consequence not only of the direct performance of professional duties of various complexity, but also depends on the holistic experience of personal activity outside work" [3, p. 171].

Occupational stress arises from occupational stress factors. All stress factors are potential stressors, not the factors that automatically cause stress. Subjects of work respond to occupational stress with sensitivity or tolerance. Based on the results of the stress factors theoretical study, the main stress factors (stressors) can be divided into four categories (see Table 1).

Factors causing occupational stress

Table 1

Factors causing occupational stress

\begin{tabular}{|l|l|}
\hline \multicolumn{2}{|c|}{ Factors causing occupational stress } \\
\hline External & $\begin{array}{l}\text { economic factors; political factors; interaction with state structures; competitive environment; } \\
\text { suppliers of resources; consumers; critical vital events; family circumstances. }\end{array}$ \\
\hline $\begin{array}{l}\text { Organizational and } \\
\text { administrative }\end{array}$ & $\begin{array}{l}\text { organizational structure; organizational processes, objectives of the activities; management system } \\
\text { in the organization; content of administrative work; means of administrative work; social and } \\
\text { psychological conditions of the organization; interpersonal interaction; factors of the production } \\
\text { environment; organizational changes; extreme conditions. }\end{array}$ \\
\hline Working & $\begin{array}{l}\text { work content, quantity of work (load); means of work; physical-chemical and technical working } \\
\text { conditions; social conditions }\end{array}$ \\
\hline Personal & $\begin{array}{l}\text { physical and physiological characteristics; social and psychological characteristics; individual and } \\
\text { psychological characteristics; moral and ethical; professional. }\end{array}$ \\
\hline
\end{tabular}

Source: it is made up by the author on a basis of $[2 ; 5 ; 6 ; 8]$.

In particular, Kh. V. Holovenko, O. M. Sopel, N. M., and Maliar-Hazda among the stress factors that affect medical staff the most, highlight such types: contact with sick people and their relatives; irregular working pattern which adversely affects the body's adaptation capacity; constant contact with other people's problems and pain ivolving negative emotions that carry negative energy; strict requirements for doctor's professional competence; responsibility for the lives and health of others; working environment; doctors and nurses' salaries, etc. $[4 ; 5]$.

V. Bozhenko, with the base on the research of psychological health conducted by I. Halytska (Lviv, 2006), and referring to A. Weitz, names eleven situations that may have a stressful character: harmful environment, the need for accelerated information processing, conscious threat; impairment of physiological functions (as a result of illness, insomnia), confinement, isolation, group pressure, ostracism (persecution), manifestation of powerlessness, inability to change the situation, the need for particularly responsible decisions, rapid change of 
behavior strategy or lack of control over events [6, p. 31-32]. Notheworthy thing is that the first eight situations are named fby A. Weitz, the last three by V. Bozhenko.

Yu. Savka, Ya. Slyvka, I. Poliak-Mytrovska, O. Raiko, and H. Savka exploring in 2018 the syndrome of professional burnout among health workers in the city of Uzhhorod [1, p. 67], having based on scientific research by V. Vinokur, O. Rybina (SPb, 2008), H. Lavrovf (Odesa, 2014), Ye. Lozynska (SPb, 2007), and L. Yuriieva (Moscow, 2004), analyzed the factors that can cause the development of professional burnout and identified seven main ones: low level of material motivation, stressful nature of professional communication, dissatisfaction with working conditions in the workplace, sex (more often women), activity (more often psychiatrists, surgeons) level of personal anxiety, and resistance to stress level.

The study of psychological prerequisites for the resiliency development of nurses conducted by O. Shevchenko (Kiev, 2018) [7, p. 302-304] deserves attention. Thus, referring to the studies of P. Hingley [10], A. McVicar [11], G. Engel [12], J. Worden [13], it should be noted that the main stress factors in nursing work are: inauspicious patient predictions; sufferings of patients; grief related to dying and death of patients; unpleasant professional tasks; inadequate training of nurses to deal with the emotional needs of patients and their families; physical, psychological, cognitive and behavioral responses of patients at the terminal stage of the disease.

In the context of our research, we note a thorough systematization of the professional stress causes highlighted in the thesis of L. Lototska-Holub (Kyiv, 2016) [8], devoted to the analysis of social and psychological resistance factors to emotional burnout in the doctors professional activity. Thus, based on the analysis of many scientific studies of the professional stresses causes (factors), L. Lototska Holub makes a generalizing conclusion that among the reasons for professional stress and professional burnout most scientists note the activity specifics, the immediate environment and individual-personal peculiarities of professionals (R. Hranovska, Yu. Povaronkov, etc.). Modern scientists consider narrow activity specialization (N. Vodopianova, Ye. Klymov, O. Noskova, and L. Mitina) as a significant factor of professional stress.

Thus, the most significant among socio-psychological factors of professional personal deformations and negative impact of occupational stress in representatives of risk groups professions can be distinguished as follows: 1) socio-psychological factors: socio-specific experience of extreme professional activity (H. Andrieieva, B. Paryhin), its parameters: character (S. Yenikopov), intensity (I. Vdovina, I. Koteniev, V. Niebylytsyn), continuity-periodicity (N. Tarabrina), duration (V. Orel) and stability of interpersonal contacts in extreme professional activity conditions (L. Kytaiev-Smyk, B. Paryhin); 2) social-family factors (V. Bodrov); 3) professional factors: professional engagement experience and special professional education (V. Bodrov, L. Shestopalova); 4) subjective factors: psychological protection mechanisms, tendency to psychosocial disorders, increased guilt, personal anxiety (Yu. Postyliakova, V. Tymchenko) and personal-sense sphere (M. Mahomed-Eminov, N. Tarabrina) [8, p. 24-25].

For objectivity, it is possible to identify stress factors that affect health workers by analyzing dominant activities, personal qualities, interests and tendencies that prevent successful professional activity. It is sufficient to carry out an analysis of the works devoted to the psychographic description of medical professions or a medical workers profession-genesis analysis. For example, the study by M. Popyl, I. Levytska [9] on the problem of optimizing the professional identity formation of future nurses with reference to the work of T. Sylkyna (Volgograd, 2002) describes the main dominant activities of nursing personnel.

Considerably if we attentively analyze nurses activity specifics, then according to it we can define a stress factors which can possibly arise and influence on: care nurse (patients' personal influence, state of patients health), treatment nurse (procedural stress factors), physiotherapeutic nurse (liability for the equipment; moral responsibility for the patient and treatment procedures accuracy), a scrub nurse (load during surgical interventions), a laboratory nurse (responsibility in careful collection of samples), a head nurse (organizational and communicative stress factors), a visiting nurse (patient influence during reception; large number of documentation; visits to patients), and by analogy to other medical professions.

To find out what stress factors, and in what quantity, cause occupational stress, we carried out diagnostics of medical workers, according to the "Causes of stress in your work" technique (Yu. Shcherbatykh). On condition of anonymity and volunteerism, the study involved 20 health workers. The expediency of using this technique is justified by the fact that it allows to determine: first, whether respondents experience the stress factors influence and second, to find out what stressors and in what quantity influence respondents.

Quantitative analysis of the data received showed that $60 \%$ of respondents experience moderate influence of professional stress factors; $35 \%$ - minor influence of stress factors; $5 \%$ - strong influence of professional stress factors. Qualitative analysis of the obtained results made it possible to determine a significant difference between the influences of professional stress factors on selected groups respondents: doctors " $D$ " and nurses "N".

It has been established that in the electoral total " $D$ " for the majority of respondents $(60 \%)$ the influence of professional stress factors is insignificant. For $40 \%$ of respondents to sample " $\mathrm{D}$ ", the impact of stress factors is moderate. "N" group respondents are overwhelmingly $(80 \%)$ moderately influenced by occupational stress 
factors. Only $10 \%$ of respondents to this group experience slight impact from professional stress factors. One respondent $(10 \%)$ indicates that there is a strong influence of professional stress factors.

After calculating the stress factor elections number that respondents made, we determined the ranks of stress factors. Attention should be paid to the top five stress factors. Thus, among the stress factors that often affect subjects of work, respondents recognized that there is a large influence of:

1) low wages $(90 \%)$;

2) lack of effective remunerative incentives in the work (85\%);

3) lack of normal conditions that are necessary for par performance ( $80 \%)$;

4) presence of additional load in work (work inconformity performed by subjects of work with their official duties) and amiss paperwork (necessity to perform unnecessary work with papers) $-50 \%$ respectively;

5) setting difficult professional tasks by management and exceeding the performed professional duties over rights $-45 \%$ respectively.

Indicators of quantitative stress-factor ranks analysis often affect subjects of work, provoking occupational stress (given in Table 2).

Results of ranking stress factors that often affect subjects of work

\begin{tabular}{|c|c|c|c|}
\hline \multirow{2}{*}{ Stress factors that often affect subjects of work } & \multicolumn{2}{|c|}{ Selections $(\mathbf{N}=\mathbf{2 0})$} & \multirow[t]{2}{*}{ Ranks } \\
\hline & abs. & $\%$ & \\
\hline Low wage & 18 & $90 \%$ & 1 \\
\hline Lack of effective remunerative incentive & 17 & $85 \%$ & 2 \\
\hline Lack of normal conditions that are necessary for par performance & 16 & $80 \%$ & 3 \\
\hline Additional load, work inconformity with official duties of work & 10 & $50 \%$ & \multirow[b]{2}{*}{4} \\
\hline Poor paperwork, extra paper work & 10 & $50 \%$ & \\
\hline Difficult professional goals setting by management & 9 & $45 \%$ & \multirow{2}{*}{5} \\
\hline Exceeding professional duties over rights & 9 & $45 \%$ & \\
\hline Weak technical base. Equipment failures & 8 & $40 \%$ & \multirow{2}{*}{6} \\
\hline Calls to management and higher authorities & 8 & $40 \%$ & \\
\hline Lack of attention to the needs of the unit by management authorities & 7 & $35 \%$ & 7 \\
\hline Insecure conditions of the working day & 6 & $30 \%$ & 8 \\
\hline Incompetence of the unit manager & 4 & $20 \%$ & \multirow{2}{*}{9} \\
\hline Negligence of employees in their duties & 4 & $20 \%$ & \\
\hline Inadequate responses of colleagues to working instructions & 2 & $10 \%$ & \multirow{3}{*}{10} \\
\hline $\begin{array}{l}\text { Unsuitable living conditions. } \\
\text { The need to think about household affairs }\end{array}$ & 2 & $10 \%$ & \\
\hline Family problems and unsuitable living conditions & 2 & $10 \%$ & \\
\hline Errors of subordinates and colleagues in work & 1 & $5 \%$ & 11 \\
\hline
\end{tabular}

It can be seen from Table 2 , that only $10 \%$ of respondents ( 2 medical workers, respondents of the "N" sample totality) among the stress factors that often affect them, and therefore provoke the occupational stress deepening, we can point out family and unsuitable living conditions.

The stress factors that are most intense in terms of the nurses exposure are shown in Table 3.

Results of ranking stress factors that often affect nurses

Table 3

\begin{tabular}{|c|c|c|c|}
\hline \multirow{2}{*}{ Stress factors } & \multicolumn{2}{|c|}{$\begin{array}{c}\text { Selections of respondents } \\
(\mathbf{N}=\mathbf{1 0})\end{array}$} & \multirow[t]{2}{*}{ Ranks of stress factors } \\
\hline & abs. & $\%$ & \\
\hline Low wage & 10 & $100 \%$ & 1 \\
\hline Lack of normal conditions that are necessary for par performance & 9 & $90 \%$ & 2 \\
\hline Lack of effective remunerative incentive & 8 & $80 \%$ & 3 \\
\hline Exceeding professional duties over rights & 7 & $70 \%$ & 4 \\
\hline Calls to management and higher authorities & \multirow{2}{*}{6} & \multirow{2}{*}{$60 \%$} & \multirow{2}{*}{5} \\
\hline Difficult professional goals setting by management & & & \\
\hline Weak technical base. Equipment failures & 5 & $50 \%$ & 6 \\
\hline Lack of attention to the needs of the unit by management authorities & 4 & $40 \%$ & 7 \\
\hline Family problems and unsuitable living conditions & 2 & $20 \%$ & 8 \\
\hline
\end{tabular}

The data in Table 3 show that among the 8 stress factors (Table 4) that often affect nurses, only 2 subjects of work $(20 \%)$ have one significant stress factor, which belongs to the personal stress factors group. Note that this is an undesirable trend for the formation of stress-overcoming behavior. The stress factors that are most intense in terms of the effect on doctors are shown in Table 4. 
Results of ranking stress factors that often affect doctors

\begin{tabular}{|c|c|c|c|}
\hline \multirow{2}{*}{$\begin{array}{l}\text { Stress factors that provoke professional stress } \\
\text { in respondents of group "D" }\end{array}$} & \multicolumn{2}{|c|}{ Selections of respondents $(\mathrm{N}=10)$} & \multirow{2}{*}{$\begin{array}{c}\text { Ranks of } \\
\text { stress factors }\end{array}$} \\
\hline & abs. & $\%$ & \\
\hline Poor paperwork, extra paper work & 10 & $100 \%$ & 1 \\
\hline Lack of effective remunerative incentive in work & 9 & $90 \%$ & 2 \\
\hline Low wage & 8 & $80 \%$ & 3 \\
\hline Lack of normal conditions that are necessary for par performance & 7 & $70 \%$ & 4 \\
\hline Negligence of employees in their duties & \multirow{2}{*}{4} & \multirow{2}{*}{$40 \%$} & \multirow{2}{*}{5} \\
\hline Tense relations in the collective & & & \\
\hline Exceeding professional duties over rights & \multirow{4}{*}{2} & \multirow{4}{*}{$20 \%$} & \multirow{4}{*}{6} \\
\hline Lack of attention to the needs of the unit by management authorities & & & \\
\hline Calls to management and higher authorities & & & \\
\hline Calls to management and higher authorities & & & \\
\hline Errors of subordinates and colleagues in work & 1 & $10 \%$ & 7 \\
\hline
\end{tabular}

Analyzing the data shown in Table 4, it can be affirmed that the stress factors that most affect doctors are: amiss paperwork; extra paper work (100\%); lack of effective remunerative incentives $(90 \%)$; low wages $(80 \%)$. So, the emergence of occupational stress among medical workers can cause both external (features of professional activity) and internal (personal features) stress factors. We consider it is necessary to note that despite the fact that the sample population of respondents was representative, however, in our opinion the obtained theoretical conclusions can help to improve understanding of professional stress factors arising in the medical workers professional activity.

Conclusions and directions for future research. The professions "doctor" and "nurse" refer to stressful. Occupational stress is a complex psychophysiological reaction of workers, which arises as a result of subjective evaluation of the external factors impact (professional-interpersonal and professional-social) under the influence of internal factors (intrapersonal). Occupational stress of health workers is caused by various stress factors, among which the main effects are: responsibility for the life and health of patients; busy schedule of work; low wages, lack of normal working conditions.

Directions for future research are also outlined. Thus, we assume that a more detailed study of the health workers stress resistance peculiarities in the conditions of crisis of present, as well as a study of the specifics of formation of health workers resistance to stress factors, should be taken into account.

\section{References:}

1. Савка Ю. М., Сливка Я. І., Поляк-Митровка І. І., Райко О. Ю., Савка Г. С. Синдром професійного вигорання у медичних працівників м. Ужгород. Проблеми клінічної педіampiï. 1 (39), 2018. C. 66-72. URL: http:// journals.uran.ua/index.php/1998-6475/issue/viewFile/9997/4451\#page=66

2. Щербакова I. М., Акентьєва Л. М. Особливості стресостійкості медичних працівників в умовах реформування медичної галузі. Людина віртуальна: нові горизонти: зб. наукових праць / за заг. ред. д. філос. н. Журби М. А. Монреаль: СРM «ASF», 2018. С. 140-142.

3. Руднєва К. Л., Кучеренко С. В. Переживання стресу медичними працівниками багатопрофільної лікарні. Гуманітарний корпус: [збірник наукових статей з актуальних проблем філософії, культурологї̈, психологї, педагогіки та історіï]. Випуск 24. Вінниця : ТОВ «ТВОРИ», 2019. С. 171-173.

4. Головенко Х. В., Сопель О. М. Поширеність синдрому емоційного вигорання у медичного персоналу і фактори, які спричиняють його розвиток. Медсестринство, 2015. № 1. С. 51-53.

5. Маляр-Газда Н. М. Емоційне вигорання - актуальна проблема медицини сьогодення. Науково-практичний журнал для педіатрів та лікарів загальної практики-сімейної медицини. 2015. № 3. С. 15-18.

6. Боженко В. Г. Стресостійкість як запорука психологічного здоров’я особистості. URL: http://jhealth. donnu.edu.ua/article/view/7489/7490

7. Шевченко О. Т. Психологічні передумови розвитку резільєнтності у медичних сестер. Збірник наукових статей Київського міжнародного університету й Інституту соціальної та політичної психології НАПН України. Серія: «Психологічні науки: проблеми і здобутки». Випуск 1 (11). К.: КиМУ, 2018. С. $297-313$.

8. Лотоцька-Голуб Л. Л. Соціально-психологічні чинники резистентності до емоційного вигорання у професійній діяльності лікарів: Дис. ... канд. психол. наук: 19.00.05. Київ. 2016. 258 c. URL: http://lib.iitta.gov. ua/166278/1/Лотцька\%20\%28все\%295.pdf

9. Попіль М., Левицька І. До проблеми оптимізації становлення професійної ідентичності майбутніх медсестер. Проблеми гуманітарних наук. Серія «Психологія». Випуск 4. С. 140-150.

10. Hingley P. The human Face of Nursing. Nursing Mirror. No. 159. 1984. P. 19-22.

11. McVicar A. Workplace stress in nursing: a literature review. Journal of Advanced Nursing. 2003 Dec. 44 (6). P. 633642. URL: https://www.ncbi. nlm.nih.gov/pubmed/14651686

12. Engel G. L. Is grief a disease? Psychosomatic medicine. 1961. № 23. P. 18-22.

13. Worden J. W. Grief Counseling and grief therapy: A hand book for a mental health practitioner. New York: Springer Publishing Company, 1991. 183 p. 